Švaříček, R., \& Šalamounová, Z. (2011). Struktura a obsah výukové komunikace mezi učitelem a žáky. In T. Janík, P. Knecht, \& S. Šebestová (Eds.), Smíšený design v pedagogickém výzkumu: Sborník príspěvkỉ z 19. výročni konference České asociace pedagogického výzkumu (s. 46-51). Brno: Masarykova univerzita.

Dostupné z: http://www.ped.muni.cz/capv2011/sbornikprispevku/svariceksalamounova.pdf

doi: 10.5817/PdF.P210-CAPV-2012-73

\title{
Struktura a obsah výukové komunikace mezi učitelem a žáky
}

\section{Structure and content of educational communication between teacher and pupils}

\author{
Roman Švaříček, Zuzana Šalamounová
}

\begin{abstract}
Anotace: Př́spěvek představuje výsledky empirické studie zaměřené na učitelské otázky a žákovské odpovědi v rámci komunikace ve školní třídě na druhém stupni základní školy. Nejprve jsou popsány učitelské otázky, které tvoří první část základní organizační struktury výukové komunikace a představuji až $70 \%$ všech interakci v hodině). Následně se př́spěvek věnuje žákovským odpovědím a popisuje některé kognitivní strategie, které mohou žáci použít při zodpovídání otázek učitele uplatnit.
\end{abstract}

Klíčová slova: IRF struktura, otázky učitele, žákovské odpovědi, kognitivní učení

\begin{abstract}
This paper presents the results of an investigation of the function of teacher questioning in selected humanities subjects at the lower secondary school. The main aim of the research was to establish the functions performed by teacher questioning in educational communication. Further we were interested in the kinds of questions teachers use in selected subjects, how teachers use open and closed questions, and how questions differ in terms of the cognitive demand factor. This is followed by a qualitative part that refers to mechanisms pupils may employ when replying to teacher questions in the effort to close in on the teacher's interpretational framework and thus achieve correct answers.
\end{abstract}

Keywords: IRF structure, teacher questioning, pupil rejoinders, cognitive learning

\section{Učitelské otázky}

Mehan se ve vlivné studii z konce 70. let minulého století pokusil popsat „sociální strukturu vyučování" (Mehan, 1979). Mehan konstatoval, že základní organizační mechanismus vyučování tvoří tzv. IRE struktura, jež zahrnuje: (1) Iniciaci, kterou typicky představuje otázka učitele, (2) Repliku, jíž je žákovská odpověd' a (3) Evaluaci, tedy učitelovo zhodnocení repliky žáka. ${ }^{1}$ Jde tedy o trrísložkovou sekvenci, kterou otevírá i uzavírá učitel. Skutečnost, že je učitel v rámci výukové komunikace dominantní, se projevuje rovněž tím, že je to ve většině př́padů on, kdo iniciuje novou komunikační sekvenci. V našem vzorku učitelé iniciovali komunikaci - obvykle položením otázky - celkem v 73 \% př́ípadů. Tyto učitelské iniciace otevírají klasickou IRF strukturu plně odpovídající nálezům Sinclaira a Coultharda (1975). A právě jim se budeme věnovat v první části textu.

Domníváme se, že je nutné posuzovat učitelskou otázku podle komunikačního záměru mluvčího realizovaného v jeho výpovědi (viz Čechová a kol., 2000). V našem vzorku jsme identifikovali 1389 otázek, to znamená v průměru 43 otázek na jednu vyučovací hodinu. Počet otázek se však v jednotlivých vyučovacích hodinách velmi liší. Nejméně jsme

\footnotetext{
${ }^{1}$ Mehan v originále používá výrazy Initiation, Reply a Evaluation - odtud zkratka IRE.
} 
zaznamenali 8 otázek (hodina literatury, kdy žáci ve dvou třetinách času prezentovali svoje referáty na téma Co jsem četl) a nejvíce 144 otázek (hodina mluvnice). Tím pádem se mění $\mathrm{i}$ čas, který mají žáci k dispozici na zodpovězení otázky. Zatímco v př́ípadě 8 otázek za hodinu jsou k dispozici více než 4 minuty na odpověd' (což ovšem neznamená, že žáci celé 4 minuty řeší odpověd' na otázku), v př́ípadě 144 otázek dostávají žáci takřka 5 otázek za minutu. To jsou však krajní polohy celého spektra.

Pro klasifikaci kognitivní náročnosti otázek učitele jsme zvolili systém Blooma (1956). Tento postup umožňuje spolehlivě určit kognitivní náročnost otázek učitele, což je pro nás podstatné. Otázka vy̌̌ši kognitivní náročnosti (higher cognitive question) je taková otázka, která splňuje dvě podmínky. Zaprvé dle Bloomovy taxonomické tabulky (Bloom, 1956) se vztahuje na otázky zaměřené na aplikaci, analýzu, syntézu a hodnocení. Zadruhé odpověd' na takovou otázku nesmí být př́mo dostupná $\mathrm{z}$ učebnice, či jiného materiálu, který mají žáci $\mathrm{k}$ dispozici.

Otázky nižši kognitivní náročnosti (lower cognitive question) jsou takové otázky, které jsou zaměřeny na doslovné vybavení si faktu, který byl již aspoň jednou v nějaké podobě učitelem prezentován.

Více než polovinu dotazů, které učitel během hodiny pokládá, tvoří uzavřené otázky nízké kognitivní náročnost zaměřené na pamětní reprodukci osvojených faktů. Naopak nejnižší zastoupení mají otázky, jejichž kognitivní náročnost je rovněž nízká, avšak jsou otevřené. Skutečnost, že učitel položí určitý typ otázky, ještě nemusí znamenat, že žákovská odpověd' s tímto typem koresponduje (viz Mareš, 1988).

\section{2 Žákovské odpovědi}

Druhá část IRF struktury, stejně jako našeho příspěvku, je tvořena žákovskými odpověd'mi na otázky učitele. Charakter žákovských promluv - jejich ne/správnost vzhledem k aktuálnímu obsahu výuky, jejich kognitivní náročnost apod., bývá zpravidla odvozován z komunikačních aktivit učitelů (srov. např. Pstružinová, 1992), ačkoli je na tento problém zkoumání výukové komunikace dlouhodobě poukazováno v českém prostředí i v zahraničí (srov. Mareš, 1988; Alexander, 2006). Pokud se totiž chceme zabývat povahou žákovských otázek, je nutné věnovat pozornost př́mo interpretační práci na straně žáka, nikoli pouze charakteru učitelovy otázky, k níž se odpověd' váže.

Jak podotýkají Edwards a Mercer (1995), učitelské otázky mohou mnohdy nabývat formy, kdy je $v$ nich včleněno vodítko $\mathrm{k}$ očekávané odpovědi, a to natolik silně, že žákovské odpovídání na otázky učitele je přeměněno v soutěž o doplňování správného slova. Žáci si přitom současně vědomi, že učitel si je vědom správné odpovědi (resp. potenciálních správných odpovědí) a že jejich odpověd' bude posuzována vzhledem k jeho očekáváním dané odpovědi (Myhill, Jones, \& Hopper, 2007), a proto je pro ně vodítko ze strany učitele určitou pojistkou jejich snahy dojít ke správné odpovědi ${ }^{2}$. Na základě tohoto nastavení je možné v rámci výukové komunikace identifikovat určité kognitivní strategie, které žáci uplatňují při odpovídání na otázky učitele.

\footnotetext{
${ }^{2}$ Že jsou žáci v této snaze většinou úspěšní, jsme prezentovali v jednom z dř́ivějších článků (Šed'ová et al., 2011).
} 


\section{Metodologie}

Data, která zde budeme prezentovat, byla pořízena $\mathrm{v}$ rámci projektu „Komunikace ve školní tř́dě“, který byl řešen na půdě Ústavu pedagogických věd Filozofické fakulty Masarykovy univerzity. Šlo o terénní výzkum etnografického charakteru. Výzkum probíhal v průběhu školního roku 2009/2010, přičemž sběr zahrnoval zúčastněné pozorování ve třídách, videostudie vyučovacích hodin, dotazníky pro žáky a hloubkové rozhovory s učiteli, na jejichž analýzu se především zaměřujeme. Vzorek tvořilo 16 různých trríd druhého stupně základní školy vyučovaných 16 různými učiteli na 4 různých školách. Vyučující, kteř́i se výzkumu zúčastnili, vyučovali ve sledovaných tř́dách český jazyk, dějepis nebo občanskou výchovu. Zkoumali jsme žáky sedmých až devátých tříd (o metodologii výzkumu více viz Švaříček, 2011).

Závěry zde předkládané nezobecňujeme na celou populaci žáků a učitelů (viz problém zobecnitelnosti - Bassey, 2001), ale pokoušíme se vytvořit důvěryhodný model, který je podložen empirickými nálezy.

\section{Shrnutí}

Kvalitativní analýza prokázala, že učitelské otázky nejsou v hodině náhodně rozloženy, ale odvisí od vzdělávacího cíle, který v dané sekvenci výukové komunikace učitel realizuje. Funkci otázek je proto vhodnější nahlédnout v delších úsecích, kdy dochází k řetězení určitého typu otázky, nikoli jen osamoceně po jedné otázce.

Pokud se učitel rozhodne, že žáci budou pouze látku opakovat (reprodukovat), pak neklade téměř žádné otázky. Jestliže se učitel zaměří na memorování určité látky právě či nedávno probírané, pak klade $\mathrm{v}$ rychlém sledu jednoduché otázky nižší kognitivní náročnosti. Velké množství uzavřených otázek nižší kognitivní náročnosti vede na jedné straně k aktivizování poměrně velké části třídy, na druhé straně jednoduché otázky učitele vyvolávají jednoduché odpovědi žáků. Jejich odpověd' není učitelem hodnocena, protože je dopředu jasné, že se jednalo o jednoduchý úkol a žáka není třeba chválit.

Teprve tehdy, když se učitel snaží přimět žáky $\mathrm{k}$ formulování svých vlastních názorů na předem dané téma, klade otevřené otázky vyšší kognitivní náročnosti.

$\mathrm{V}$ návaznosti na popis celého repertoáru učitelských otázek se zaměříme na dvě vybrané žákovské strategie, na nichž bude demonstrováno, kterak mohou žáci postupovat při hledání odpovědí na otázky učitele. První z nich označujeme jako odpověd’ na základě kolokability, spojitelnosti slov (Encyklopedický, 2002). Zásadní charakteristikou kolokability je přitom skutečnost, že frekventované opakování spojení určitých slov může vést až k procesu automatizace, kdy si spolu s určitým slova okamžitě vybavíme i slovo, které se s ním často váže. Př́kladem může být výňatek $\mathrm{z}$ hodiny učitelky Jitky, která se žáků ptá na vynálezy různých slavných osobností:

\section{Ukázka č. 1:}

Učitelka: Vám budu za chvilku číst, že tam James Watt vymyslel parní? ((kouká na levou řadu))

Žák: Stroj. 
Rizikem u tohoto typu žákovských replik je fakt, že žáci nemusejí správnou odpověd’ znát, př́padně nemusejí vědět, jaký je obsah daného pojmu. Pokud však mají k dispozici první slovo či slova požadovaného sousloví (např̀. stavovské - povstání, zlatá bula - sicilská, v uvedeném př́padě parní - stroj), jsou schopni odpověd' automaticky i bez hlubší znalosti doplnit ke spokojenosti učitelky. Tato strategie přitom může být uplatněna také u otázek vyšší kognitivní náročnosti (srov. Makovská, 2011).

Sekvence, v níž jsou žáci naváděni k odpovědi v závislosti na kolokabilitě jednotek, jsou atypické také svou strukturou - jedná se o mechanismus, v němž učitel pokládá nedokončenou otázku, čímž žákovi dává signál k jejímu doplnění. Žákovské repliky lze v tomto př́padě označit za tzv. nepravé odpovědi. Nejedná se totiž o odpovědi ve vlastním slova smyslu - učitelská otázka a žákovská odpověd' dohromady vytvářejí jednu ucelenou větu, nikoli samostatně stojící otázku a odpověd', jak tomu je všech ostatních případech.

Druhou strategií, kterou budeme na tomto místě prezentovat, je odpověd' analogií. V tomto př́padě žáci duplikují mechanismus, který byl využit $\mathrm{v}$ předcházejících sekvencích některým ze spolužáků (v některých př́ípadech také žákem samotným) a učitelem uznán za správný. Žáci tak volí slovo, které je analogické k odpovědi uznané jako požadované, čímž stoupá pravděpodobnost, že bude také jejich odpověd' uznána jako správná. Př́ikladem může být výňatek z hodiny učitelky Marcely, která se žáků ptá, ve kterých oblastech života jsou patrná folklórní specifika:

\section{Ukázka č. 2:}

Učitelka: Co by asi patřilo tady mezi ty zvyky, pravidla. Co myslíte?

Žák Aleš: Vánoce.

Učitelka: Každý Vánoce, (prst před ústa, naznačuje, že se žáci mají ztišit) každý Vánoce slavíme jinak. Takže tam jsou nějaké zvyky, třeba ten folklór by sem mohl patřit, co jste říkali. Co dál?

Žák Adam: Velikonoce.

Učitelka: Tak to jsou ty svátky.

Žákyně Mirka: Valentýn.

Učitelka: Tak to jsou zase ty svátky. (usmívá se)

Žák David: Že když je nějaký významný den, tak že někdo na to kašle a někdo to jako dodržuje.

Učitelka: Tak to zas souvisí se svátky.

První z žáků přichází z odpovědí, že folklórní zvyklosti jsou patrné v době Vánoc, což je učitelkou uznáno jako správná odpověd'. Ostatní žáci proto postupují analogicky, taktéž volí odpovědi, které mají stejné slovo nadřazené, nejrůznější svátky. Na to, že žáci odpovídají analogicky, se snaží poukázat také učitelka (to jsou zase ty svátky), žáci se však již k jiné než k vybrané a „zaručeně správné“ kategorii odpovědí neuchylují. Z této ukázky je současně patrné, že ačkoli učitelka otázku formuluje jako otevřenou otázku vyšší kognitivní náročnosti, žáci mohou toto zadání svými kognitivními strategiemi obejít tak, aby měli jistotu správné odpovědi (více viz Šed’ová, Švaříček, \& Šalamounová, 2011). 


\section{Poděkování}

Autoři děkují všem učitelům a žákům, kteří byli ochotni se výzkumu účastnit, a umožnili tak jeho realizaci. Dále děkujeme za podporu projektům Komunikace ve školní třídě (GA406/09/0752) a Škola: výzkum vnitřních procesů a vnějších podmínek jejího fungování (GA406/09/H040), díky nimž mohl vzniknout tento článek.

\section{Literatura}

Alexander, R. (2006). Towards dialogic teaching: Rethinking classroom talk. Cambridge: Dialogos.

Bassey, M. A. (2001). Solution to the problem of generalisation in educational research: Fuzzy prediction. Oxford Review of Education, 1(27), 5-22.

Bloom, B. S., et al. (1956). Taxonomy of educational objectives. The classification of educational goals. Handbook I: Cognitive domain. New York: Longmans Green.

Čechová, M. (2000). Čeština - ̌reč a jazyk. Praha: ISV nakladatelství.

Edwards, A. D., \& Mercer, N. (1995). Common knowledge. The development of understanding in the classroom. London and New York: Routledge.

Encyklopedický slovník češtiny. (2002). Praha: Nakladatelství Lidové noviny.

Makovská, Z. (2011). odpovědí itele. Studia paedagogica, $1(16), 47-70$.

Mareš, J. (Ed.). (1988). Pedagogická interakce a komunikace. Hradec Králové: PdF UHK v Hradci Králové.

Mehan, H. (1979). Learning lessons. Social organisation in the classroom. Cambridge: Harvard University Press.

Myhill, D., Jones, S., \& Hopper, R. (2007). Talking, listening, learning. London: Open University Press.

Parker, M., \& Hurry, J. (2007). Teachers'use of questioning and modeling comprehension skills in primary classrooms. Educational Review, 59(3), 299-314.

Pstružinová, J. (1992). Některé pedagogicko psychologické aspekty učitelských otázek. Pedagogika, 2(42), 223-228.

Sinclair, J. M., \& Coulthard, M. (1975). Towards an analysis of discourse: The English used by teachers and pupils. London: Oxford University Press.

Šed’ová, K., Švaříček, R., Makovská, Z., \& Zounek, J. (2011). Dialogické struktury ve výukové komunikaci na druhém stupni základní školy. Pedagogika, 1(61), 13-34.

Šed’ová, K., Švaříček, \& R. Šalamounová, Z. (2011). Komunikace ve školni tř́dě. Praha: Portál. (v tisku).

Švaříček, R. (2011). Funkce učitelských otázek ve výukové komunikaci na druhém stupni základní školy. Studia paedagogica, 16(1), 9-46.

\section{Kontakt}

Mgr. Roman Švaříček, Ph.D.

Mgr. Zuzana Šalamounová

Masarykova univerzita

Filozofická fakulta, Ústav pedagogických věd

A. Nováka 1, 60200 Brno

e-mail: svaricek@phil.muni.cz

zmakovska@phil.muni.cz 


\section{Bibliografické údaje}

Švaříček, R., \& Šalamounová, Z. (2011). Struktura a obsah výukové komunikace mezi učitelem a žáky. In T. Janík, P. Knecht, \& S. Šebestová (Eds.), Smišsený design v pedagogickém výzkumu: Sborník př́spěvků z 19. výročni konference České asociace pedagogického výzkumu (s. 46-51). Brno: Masarykova univerzita.

Dostupné z: http://www.ped.muni.cz/capv2011/sbornikprispevku/svariceksalamounova.pdf doi: 10.5817/PdF.P210-CAPV-2012-73 